\title{
Developing Skills of Early Childhood Teachers Through Tales Writing Training and Presentation Techniques in East Lombok
}

\author{
Sandy Ramdhani ${ }^{1 *}$, Eva Nurmayani ${ }^{2}$
}

\author{
Education Faculty, Universitas Hamznawadi Pancor, NTB, Indonesia \\ Language, Art And Humanities Facult, Universitas Hamznawadi Pancor, NTB, Indonesia \\ *Corresponding author. Email: sandy160392@gmail.com
}

\begin{abstract}
One of several problems of early childhood teachers in the district of East Lombok is difficult to find content that is both contemporary fairy tales or contemporary. The situation is certainly cause confusion when the teacher would tell a story or fable yng contextual, in accordance with the demands of the model and current learning materials. Therefore, it takes intensive training to help teachers produce its own tale to be served course by using a good standard of writing a fairy tale. Based on the review conducted on the skills of teachers in the moments before the training to write a story (pre-training) and after training (post-training) is found if the result of the response of teachers and shows the average value of 4 .
\end{abstract}

Keywords: Fairytale skills, early childhood teachers, training, presentation techniques

\section{INTRODUCTION}

Ramdhani (Ramdhani et al., 2019) To explain educators nation-building is a major milestone which has a central role in human Indonesia produces a superior and competitive. As a major milestone development, teachers must perform the obligation to teach it to the maximum. One way to maximize the obligation to participate in various training and useful training to improve teachers' skills in various aspects of learning.

Acquired skills teachers must be determined by the specification mandates(Yanuarsari and Muchtar, 2016; Alkaaf, 2017). Teachers as educators is one example of educator profession who has extraordinary mandate to produce a superior generation early on. Precisely at the golden period in which a child's brain at that time is growing rapidly (Maureen, van der Meij and de Jong, 2018), Therefore, early childhood teachers must continue to align the skills possessed by various epoch. A successful learns in early childhood, especially methods and mastery of the learning process in the classroom

One of mastery to be possessed by the teacher is mastery of technique or skill in storytelling and writing fairy tales. The ability of storytelling and presentation techniques with good storytelling ability and mastery of technique presentation of fairytale by teachers can actually lure and bring many benefits, not only for children, but also parents or teachers tell stories to children or students(Yanuarsari and Muchtar, 2016; Allard and Doecke, 2017), (Fitroh et al., 2015)Through writing stories, treasures of knowledge of early childhood teachers will be growing and could be utilized in education so that the values of life and can be infused with a maximum character.

The role of educators in building the character of early covers four things: (1) teachers as educators; (2) educators as role models; (3) educators as designer development, and (4) educators as a consultant and mediator (Allard and Doecke, 2017; Ayuningtyas, Effendy and Kaburuan, 2018). The fourth is based on the teacher's role, the role can be carried out by a third early childhood teachers to produce works of fairy tales can be maximized by the teacher in the learning process. Through stories, teachers can convey the message, either the message of religious, moral, social, or cultural without being limited to a particular figure(Willhite, 2017)).

(Hadzigeorgiou, 2016; Maureen, van der Meij and de Jong, 2018; Sunday, 2018) Describe the method of storytelling is an effective way to embed a range of values, especially for literacy and the development of character values and morals. through storytelling children will be able to better understand the meaning of development, especially on the virtues mythical delivered. To the teachers' skills in writing, a fairy tale should be maximized with a variety of 
businesses, form of training or education and training can be used as a vehicle to improve teacher skills in storytelling and or produce fairytale. One of several problems of early childhood teachers in East Lombok difficult to find content that is both contemporary fairy tales or contemporary. The situation is certainly cause confusion when the teacher tell a story or fable contextual, in accordance with the demands of the model and current learning materials. Therefore, it takes intensive training which enables teachers to generate their own tale to be served course by using a good standard of writing a fairy tale. Thus, the implementation of learning in the classroom can be run with the maximum. Based on previous exposure,

Inspiration writer to perform a review of the importance of skills development through training early childhood teachers writing fairy tales have been implemented through community service activities so they can know the optimal level of training delivery skills of writing a fairy tale to the development of early childhood teachers. Storytelling or storytelling in early childhood (Amalia, 2018.; Ayuningtyas et al., 2018; Loniza, Saad, and Che Mustafa, 2018) is a method that has a Drag and touching the child. Storytelling is the process of telling someone using vocal abilities, structured narrative, and mental images with a listener to the communicate (Nguyen et al., 2015; Loniza, and Che Saad Mustafa, 2018), Therefore, the ability of the teacher as an innovator, especially d early childhood learning should give a good touch, especially in the mastery of storytelling ability and presentation techniques.

\section{METHOD}

The research is qualitative research. Type of qualitative research approach used is descriptive qualitative approach in which the data obtained are derived from the implementation of training activities through storytelling and presentation techniques. The subjects were used as a sample is to use early childhood teachers in the county of East Lombok with a number of samples were 30 teachers. Data collection techniques used is by using the used sheets of observation on the activity of storytelling and presentation techniques, interviews to determine changes in the ability of teachers to write a story, and Documentation. Data collection instrument was the human instrument, interview and observation data sheet analysis technique used to classify data based on variables and types of respondents, shows data for each variable, perform calculations to obtain the results of Storytelling Training and Presentation Techniques. In qualitative research there are a lot of data analysis that can be test the validity of the data for this study was based on four criteria: the degree of confidence (credibility test), Fatigue (Test transferability), dependence (dependability) and certainty (confirmability) (Ramdhani et al., 2019), The process of data analysis was performed using an interactive model Miles \& Huberman (2001), including: (1) Data collection to collect data on the ability of storytelling and presentation techniques early childhood teachers in East Lombok; (2) Display data from the various instruments that are used ranging from interviews, observation and documentation of the activities; (3) Reduction of Data by selecting the results of data collection instruments include the results of the data, the results of applying the method of storytelling and presentation techniques (Conclusion Drawing) (Miles \& Hubberman. 2001).

\section{RESULTS AND DISCUSSION}

\section{Research result}

The data found in the field of interviews with teachers in early childhood education in sub Selong, namely TK Hamzanwadi Pancor, RA Selong and TK Dharma Wanita AlAsh'ari Reban Sandubaya Sugarcane found that teachers have difficulty writing because during these fairy tale teachers more often directed at a training presentation, not the writing. Although storytelling activities carried out in the classroom, the teacher only uses the fairy tale content of a general nature that are usually found in bookstores or on the internet search results

Based on the opinions of respondents who participated in the training organized can be seen the consistency of the responses given, in other words, the average response of the teachers stated strongly agree and agree with the fairy tale writing training and presentation techniques are implemented. The translation process is described in the following results: The information obtained by the response of teachers after the training the writing and presentation of a fairy tale with an affinity for training results of training in the classroom, is $30 \%$ of teachers said "strongly agree" and $70 \%$ of teachers said "agree" with training writing and presentation techniques implemented the fairy tale. Based on the average for all of the items and respondents with respect to the response of teachers to the writing and presentation training for 4,408 fairy tales. These results when converted in the category "agreed" that it could be concluded that the average teacher provide an excellent response to the training of writing and presentation techniques based on local wisdom of fairy tales as a child trauma treatment effort after the earthquake in Lombok 2018

\section{Discussion}

Master the skills of early childhood Pre Tale Writing Training

In the National Education Minister Regulation No. 58 of 2009 declared that the kindergarten must develop five aspects of development. Aspects it is an aspect of religious values and moral, socio-emotional, physical aspect-motor, 
cognitive, and last literacy aspect, the aspect of language has a clear correlation with the storytelling method that can be used by teachers in practice learning in the classroom because it is one skill or skills that must be taught. Thus, early childhood teachers must have the skill or skills before to the training in class(Yuksel-Arslan, Yildirim and Robin, 2016; Allard and Doecke, 2017),

(Limarga, 2017; Nur Azizah and Ali, 2018; Oduolowu \& Oluwakemi, 2014)The use of fairy tale content that does not comply with the environmental conditions around the students also become one of the obstacles teachers in tucking the values of local wisdom which is owned by the local community. As one example, teachers sometimes choose Malin Kundang story to convey a message of moral, social, and religious. However, students or learners also often ask, what exactly is meant Malin Kundang stone. Although Tale as work of fiction, by definition, the fairy tale is a story about the behavior of a character by using like or comparison(Cremin et al., 2018; Sunday, 2018; Brodin and Renblad, 2019) describes reality only fictitious but in the context of education and learning, any material submitted must have a relationship with the real condition of students or learners so that the values instilled especially the values of character to be well received. In this case the use of content myth from different areas is not a problem but it would be great if accompanied by a fairy tale that is local.

Another issue that was discovered by the teacher in storytelling, which at the time of an emergency. Teacher sometimes up the story by choosing or make certain characters and scenes with different properties (flow of life) who lived with adjusted based on the material or theme that learned. However, until now the teachers are able to make the fairytale is necessarily not been able to put the idea or his idea in the form of paper. Even this condition is only done by some teachers who generally prefer reading material so as to generate ideas unstructured(Catala et al., 2017; Ramdhani et al., 2019),

In fact, the problems found by the interviews that have been made could be one of the obstacles the development of children's language skills. In fact, the child's language development can be done through a method of storytelling or recalled, according to the results of research studies conducted(Junaidi, 2017) which found that if the storytelling method can improve the child's ability to speak significantly. The opinion expressed by almost the same (Yuksel-Arslan, Yildirim and Robin, 2016; Sunday, 2018) there is a significant correlation between the ability to speak the child with fairy tales or stories commonly heard. With the detection of this problem, is expected to be one of the bases for the implementation of a fairy tale writing training given to early childhood teachers in East Lombok district so it is important to review what kind of response and skills after training early childhood teachers to write a story.

\section{Master the skills of early childhood Post Writing Training Tale.}

The problem some early childhood teachers who have not participated in the training of writing a fairy tale to be reduced after the training that proceed Program Early Childhood Education University Hamzanwadi Selong in cooperation with the Ministry of Research, Technology and Higher Education (Kemenristek Higher Education) participation involving students from two courses, namely PBSI (Indonesian Language and Literature Education) and PG-AUD (Early Childhood Teacher Education). On average teachers give positive response and more confident in writing fairy tales. As evidenced by the few works that have been generated and ready to be printed. Participants who have attended training also states the additional knowledge gained from the training followed because teachers and students are more

The conclusions are based on the analysis of questionnaires or instrument that has been deployed in some of the early childhood school in the district of East Lombok. Here is a list of names of participants, the school of origin, and the response is supplied complete with a bar chart of analysis results. Based on the average for all of the items and respondents with respect to the response of teachers to the training of the writing and presentation of a fairy tale for 4,408 and 4,270. These results when converted in the category of "good" so that it can be concluded that the average teacher provide an excellent response to the training of writing fairy tales that have been implemented.

\section{CONCLUSION}

Based on interviews and questionnaires (instruments) that spread can be concluded that the fabled writing training is needed by early childhood teachers, especially in East Lombok. Through a fable writing training, early childhood teachers become more skilled, especially in carrying out its duties, namely in developing the language skills of young children. Based on the results obtained can be seen holding the consistency of the responses given, in other words, the average response of teachers agree and strongly agree with the writing and presentation of a fairy tale training offered. Therefore,

\section{ACKNOWLEDGMENTS}

Thanks to the Directorate of Research and Community, University Hamzanwadi, Early Childhood School Partner. 


\section{REFERENCES}

Alkaaf, F. (2017) 'Perspectives of learners and teachers on implementing the storytelling strategy as a way to develop story writing skills among middle school students', Cogent Education. Cogent, 4(1), pp. 1-23. doi: 10.1080/2331186X.2017.1348315.

Allard, A. C. and Doecke, B. (2017) 'Telling tales: the value of storytelling for early career teachers', Pedagogy, Culture and Society. Routledge, 25(2), pp. 279-291. doi: 10.1080/14681366.2016.1253602.

Amalia, T. Z. (no date) 'Mengajar Bagi Guru Raudlatul Usia Dini Di Desa Ngembalrejo', 28(2).

Ayuningtyas, O. D. J., Effendy, V. and Kaburuan, E. R. (2018) 'User interface modelling by implementing storytelling on Sundanese cultural introduction media for early childhood using child-centered design method', IOP Conference Series: Materials Science and Engineering, 434(1). doi: 10.1088/1757899X/434/1/012278.

Brodin, J. and Renblad, K. (2019) 'Improvement of preschool children's speech and language skills', Early Child Development and Care. Taylor \& Francis, 0(0), pp. 1-9. doi: 10.1080/03004430.2018.1564917.

Catala, A. et al. (2017) 'Storytelling as a creative activity in the classroom', $C$ and $C 2017$ - Proceedings of the 2017 ACM SIGCHI Conference on Creativity and Cognition, pp. 237-242. doi: 10.1145/3059454.3078857.

Cremin, T. et al. (2018) 'Storytelling and story-acting: Coconstruction in action', Journal of Early Childhood Research, 16(1), pp. 3-17. doi: 10.1177/1476718X17750205.

Fitroh, S. F. et al. (2015) 'Dongeng Sebagai Media Penanaman Karakter Pada Anak Usia Dini', $P G$ PAUD Trunojoyo, 2.

Hadzigeorgiou, Y. (2016) Imaginative science education: The central role of imagination in science education, Imaginative Science Education: The Central Role of Imagination in Science Education. doi: 10.1007/9783-319-29526-8.

Junaidi, F. (2017) 'the Value of Character Education in Andai-Andai Folklore and Its Use As Learning Material for', III(9), pp. 501-509.

Leversund, A.H., Krzywinski, A. and Chen, W., 2014, June. Children's collaborative storytelling on a tangible multitouch tabletop. In International Conference on Distributed, Ambient, and Pervasive Interactions (pp. 142-153). Springer, Cham

Luke, A. and Kale, J., 2017. Learning through difference: Cultural practices in early childhood language socialisation. In One child, many worlds (pp. 11-29). Routledge.
Limarga, D. M. (2017) 'Penerapan Metode Bercerita Dengan Media Audio Visual Untuk Meningkatkan Kemampuan Empati Anak Usia Dini', Tunas Siliwangi, 3(1), pp. 86-104. Available at: http://search.ebscohost.com/login.aspx?direct=true\&d $\mathrm{b}=\mathrm{buh} \& \mathrm{AN}=4407911 \&$ site $=$ ehost-live.

Loniza, A. F., Saad, A. and Che Mustafa, M. (2018) 'the Effectiveness of Digital Storytelling on Language Listening Comprehension of Kindergarten Pupils, The International journal of Multimedia \& Its Applications, 10(06), pp. 131-141. doi: 10.5121/ijma.2018.10611.

Maureen, I. Y., van der Meij, H. and de Jong, T. (2018) 'Supporting Literacy and Digital Literacy Development in Early Childhood Education Using Storytelling Activities', International Journal of Early Childhood. Springer Netherlands, 50(3), pp. 371-389. doi: 10.1007/s13158-018-0230-z.

Miles \& Hubberman. 2001. Qualitative Data Analysis. Oxford: SagePublisher

Nguyen, K. et al. (2015) 'A comparative study on storytelling perceptions of Chinese, Vietnamese, American, and German education students', Reading Psychology, 37(5), pp. 728-752. doi: 10.1080/02702711.2015.1105340.

Nur Azizah, A. and Ali, M. (no date) 'Penanaman Nilai Moral Melalui Metode Bercerita Pada Anak Usia 5 6 Tahun Di Tk Khodijah', pp. 1-16.

Oduolowu, E. and Oluwakemi, E. (2014) 'Effect of Storytelling on Listening Skills of Primary One Pupil in Ibadan North Local Government Area of Oyo State, Nigeria', International Journey of Humanities and Social Science, 4(9), pp. 100-107. Available at: http://www.ijhssnet.com/journals/Vol_4_No_9_July_ 2014/10.pdf.

Parks, A.N. and Wager, A.A., 2015. What knowledge is shaping teacher preparation in early childhood mathematics?. Journal of Early Childhood Teacher Education, 36(2), pp.124-141.

Ramdhani, S. et al. (2019) 'Penanaman Nilai-Nilai Karakter melalui Kegiatan Storytelling dengan Menggunakan Cerita Rakyat Sasak pada Anak Usia Dini', Jurnal Obsesi : Jurnal Pendidikan Anak Usia Dini, 3(1), p. 153. doi: 10.31004/obsesi.v3i1.108.

SPARC (Organization), A. and Willhite, G. L. (2017) 'International electronic journal of elementary education.Teacher efficacy in an early childhood professional development school', International Electronic Journal of Elementary Education, 7(2), pp. 189-198. Available at: https://iejee.com/index.php/IEJEE/article/view/74.

Stagnitti, K., Bailey, A., Hudspeth Stevenson, E., Reynolds, 
E. and Kidd, E., 2016. An investigation into the effect of play-based instruction on the development of play skills and oral language. Journal of Early Childhood Research, 14(4), pp.389-406

Sunday, K. E. (2018) 'Drawing and Storytelling as Political Action: Difference, Plurality and Coming into Presence in the Early Childhood Classroom', International Journal of Art and Design Education, 37(1), pp. 6-17. doi: 10.1111/jade.12097.

Yanuarsari, R. and Muchtar, H. S. (2016) 'Improving Early Childhood Teachers' Skills Through Story Telling Workshop', PEOPLE: International Journal of Social Sciences, 2(1), pp. 533-543. doi: 10.20319/pijss.2016.s21.533543.

Yuksel-Arslan, P., Yildirim, S. and Robin, B. R. (2016) 'A phenomenological study: teachers' experiences of using digital storytelling in early childhood education', Educational Studies, 42(5), pp. 427-445. doi: 10.1080/03055698.2016.1195717. 